\title{
ANALYSIS OF A WETLAND SYSTEM IN THE POST-TREATMENT OF WASTEWATER
}

Carlos Eduardo Zacarkim ${ }^{2}$, Luciano Caetano de Oliveira ${ }^{2}$, Rosilene Andrea Welter ${ }^{3}$, Nayara Szymanski ${ }^{3}$, Fernando Rodolfo Espinoza Quiñones ${ }^{3,4}$, Soraya Moreno Palácio ${ }^{3,4}$, Simone Damasceno $^{4}$

\footnotetext{
${ }^{1}$ Aceito para publicação no $1^{\circ}$ trimestre de 2014

${ }^{2}$ Associate Professor, Laboratory of Ecology, Ichthyology and Fisheries - LEPI / Federal University of Paraná UFPR. Street Pioneers, 2153, CEP 85950-000, Palotina, Paraná, Brazil. Email Address: zacarkim@ufpr.br ${ }^{3}$ Associate Professor, State University of West Paraná - UNIOESTE.

${ }^{4}$ Postgraduate in Chemical Engineering, State University of West Paraná - UNIOESTE.
}

\begin{abstract}
The study was based on a surface flow wetland system, using the macrophyte Eicchornia crassipes. The use of wetlands as an alternative in the wastewater treatment process has been employed due to the handling and simple technology, addition to the low cost compared to conventional systems. Three hydraulic retention times, they are 4, 6 and 8 days were analyzed. In general the system showed significant results in relation to removals of nutrients for all TRH reviews, where the hydraulic retention time of 6 days achieved the best performance. The proposed system achieved $79.91 \%$ reductions for COD, $83.51 \%$ of Total Phosphorus, Total Nitrogen $67.93 \%, 87.7 \%$ chromium and $52 \%$ Sulfur.
\end{abstract}

Key-words: Wetland, aquatic macrophytes, wastewater.

\section{ANÁLISE DE UM SISTEMA WETLAND NO PÓS-TRATAMENTO DE ÁGUAS RESIDUAIS}

\section{Resumo}

O estudo foi baseado em um sistema wetland de fluxo superficial, utilizando-se a macrófita aquática Eicchornia crassipes. O uso de wetlands como alternativa no processo de tratamento 
de águas residuais vem sendo empregado devido ao manejo e tecnologia simples, além do baixo custo em relação a outros sistemas convencionais. Foram avaliados três tempos de retenção hidráulica, sendo eles 4, 6 e 8 dias. De modo geral o sistema apresentou resultados significativos em relação a remoções de nutrientes para todos os TRH avaliados, onde o tempo de retenção hidráulica de 6 dias obteve o melhor desempenho. O sistema proposto obteve reduções 79,91\% para DQO, 83,51\% de Fósforo total, 67,93\% de Nitrogênio total, $87,7 \%$ de Cromo e de $52 \%$ de Enxofre.

Palavras-chave: Wetland, Macrófitas aquáticas, águas residuais.

\section{Introducion}

Technologies of wastewater treatment in built flooded areas have been used since 1970. These techniques are based not only on biotic processes that contemplate the action of microorganisms and nourishment absorption by the plants introduced in solution at the environment, but also they contemplate abiotic process that include chemistry precipitation, sedimentation and adsorption of ions on the substrate (Lin et al, 2005; Álvarez \& Bécare 2008; Tang et al 2009).

The built wetland are systems artificially projected to use aquatic plants (macrophyte) on substrates such as sand, graves or any other inert material, on which occurs the proliferation of biofilms that aggregate several populations of microorganism, which, through biological, chemical and physical process, treat the wastewater. They are distinguished for presenting moderated capital cost, low energy consumption and maintenance, landscapes aesthetics and increase of wildlife habitat (IWA, 2000; Ruan et al., 2006; Hedmark et al., 2009; McJannet et al., 2012).

Build wetlands imitate natural swamps, recently being amongst the most effective wastewater treatment. They have been used as a low cost alternative for secondary and tertiary conventional sewage treatment. There are three types of built wetland: Superficial Flow, Integrated Vertical Flow and Subsurface Flow. Opposed to the superficial flow systems and the integrated vertical, there is the subsurface flow, which its investment and operation cost are lower, however, it occupies larger structural areas, besides presenting reduced efficiency regarding the treatment when compared to the others (Ruan et al., 2006; Chen et al., 2008; Jou et al., 2009). 
Considering the industrial wastewater, the ones derived from the leather industry stand out. According to Imhoff (1985), wastewater from tannery is highly polluted. Besides having putrescible substances, they contain toxic salts, alkalis and sulfur compounds. Tannery presents high water consumption, from 25 to $30 \mathrm{~m}^{3}$ per ton of salted skin or $630 \mathrm{~L} / \mathrm{salted}$ skin, in average, that varies according to the processes used, according to the management, and other factors.

A midsize tannery that process 3.000 salted skins.day ${ }^{-1}$, consume roughly $1.900 \mathrm{~m}^{3}$ water.day $^{-1}$,which is equivalent to the diary consumption of a population with 10.500

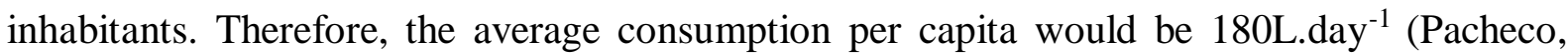
2005).

Considering the environmental problems caused by the leather industry, the goal of this paper was to evaluate the nourishment absorption in a wetland system built on a pilot scale, using macrophyte Eicchornia crassipes on the post treatment of tannery effluents, in view of enlightening the hypothesis that the system will reduce the high load of pollutants.

\section{Material e methods}

The present work is about a toxicological testing and operation of a wetland system on a pilot scale, installed and conducted in the city of Toledo - PR, located in the geographical coordinates $24^{\circ} 43^{\prime} 26^{\prime}$ 'S and $53^{\circ} 45^{\prime} 11^{\prime \prime} \mathrm{W}$. The system is constituted of a superficial flow wetland, compounded by a battery of four tanks, shaped like gutters, presenting usable volumes of 215L each gutter (Figure 1), using macrophyte Eicchornia crassipes and operated with tannery effluents located at the region (Chen et al., 2008; Álvarez \& Becares 2008; Hu \& Shan, 2009).

The choice of macrophyte, used in this test, was based on the information collected from the scientific literature, evaluating its level of absorption and its growth. They were weighted and a accommodated in a density of 5,9 kg.plant. $\mathrm{m}^{2}$ of liquid surface (EspinozaQuinoñes et al., 2005; Ruan et al., 2006; Chen et al., 2008; Cui et al., 2008; Hu \& Shan, 2009). 


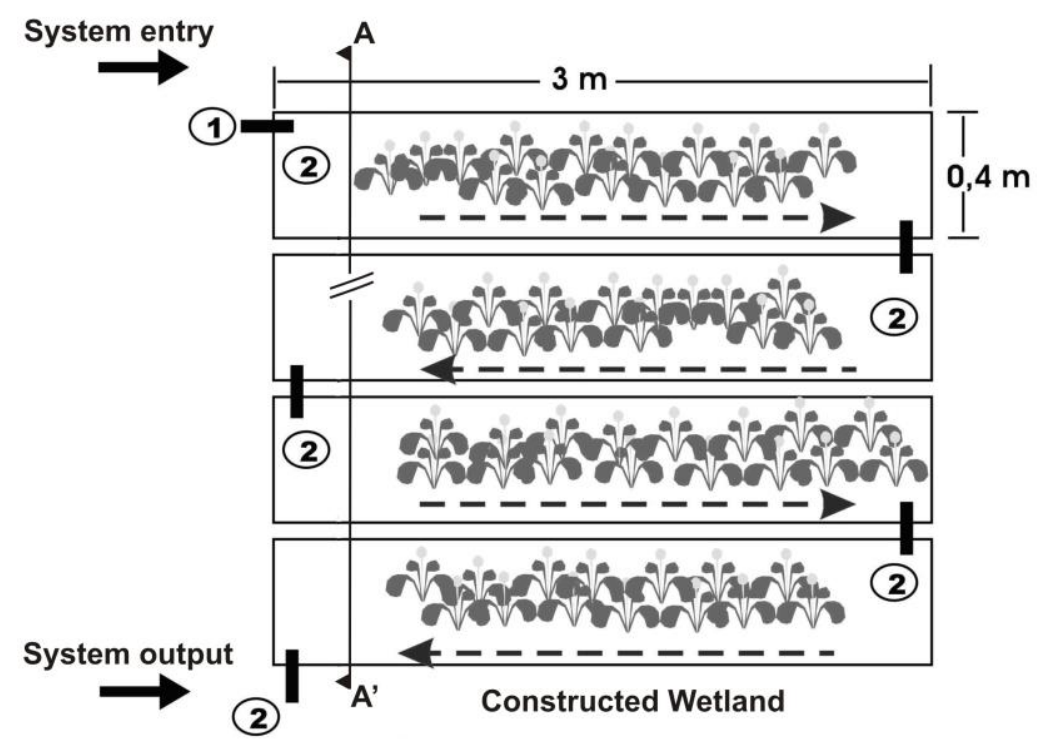

Cut A - A'
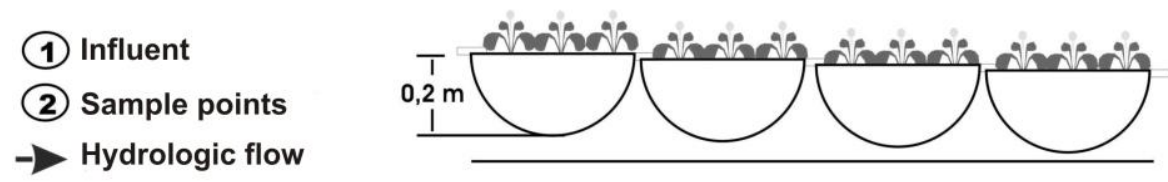

Figura 1. Wetland system detailing on a pilot scale.

The toxicological testing of this work was performed considering the goal of finding the most adequate effluent concentration to the tolerance of the macrophyte chosen for the study. The dilutions tested were: raw tannery effluent, 3/4 (75\%), 1/2 (50\%) 1/5 (20\%) and 1/10 (10\%). The design applied on this test was entirely randomized (DIC), on which, it was evaluated the macrophyte survival rate within the period of seven days, performed in rejoinders, submitted to analysis of variance and the averages compared by Tukey test, 5\% significance (Espinoza-quinones et al., 2005; Espinoza-Quiñones et al., 2008; Hu \& Shan 2009).

Once the toxicological test was performed, the evaluation of the wetland system was started, on which three Hydraulic Retention Times were tested (HRT). They were: 4, 6 and 8 days for 5 weeks each time. The evaluated parameters on this test were: $\mathrm{pH}$, Temperature, Total Nitrogen, COD, Total Phosphor, according to Standad Metods (APHA, 2005), and Chrome and Sulfur were evaluated by the X-Ray Fluorescence technique, known as XRF (Espinoza-Quiñones et al., 2008). 
In this technique, the amount of metals dissolved in the effluents are evaluated with accuracy, considering a aliquot of $60 \mathrm{~mL}$ for each sample, separated and filtrated through a Milipore filtration system with a $47 \mathrm{~mm}$ membrane of diameter of cellulose acetate with pores of $0,45 \mu \mathrm{m}$. After filtrating, in each $10 \mathrm{~mL}$ alíquota from each sample, it was added $10 \mu \mathrm{L}$ of yttrium solution (Y 11,6 g/ $/ \mathrm{l}^{-1}$ ), as internal standard. $5 \mu \mathrm{L}$ aliquots were deposited in the precleaning of acrylic discs ( $\varnothing \square 32 \mathrm{~mm}, 3 \mathrm{~mm}$ thickness) and dried at room temperature. For the XRF analysis, the samples with dry wastes were irradiated with a polychromatic X-ray beam with maximum energy of $20 \mathrm{keV}$, at the Synchrotron Light National Laboratory (translated from the Portuguese and stands for Laboratório Nacional de Luz Síncrotron - LNLS), in Campinas, São Paulo, Brazil. The X-ray spectrums were analysed using AXIL software. Using a calibration curve for the XRF system, the concentrations of the metals dissolved in the effluents were determined. The sample points were taken by the end of each gutter from the system, performed in rejoinders, in order to provide the statistic treatment.

\section{Results and discussion}

\section{Toxicological Tests}

Amongst the concentrations tested during the toxicological test, it was chosen to operate with effluents diluted $1 / 2(50 \%)$, because they presented better survival and tolerance conditions for the effluent tested, not presenting significant difference ( $>>0,05)$ among the samples. In concentrations with higher dilution (more than $1 / 2$ or $50 \%$ ), macrophyte presented higher mortality, with significant difference $(\mathrm{p}>0,05)$, according to the test of Tukey.

\section{Characterization of the effluent}

Table 1 presents the average concentration values of the parameters analyzed for the chosen effluent during the experiment performance.

Tabela 1. Characterization of the effluent worked post-process of wastewater treatment applied at the studied tannery. Average values in mg.L $\mathrm{L}^{-1}$ sampled during the HRT evaluated. 


\begin{tabular}{lcccc}
\hline Parameter & $\begin{array}{c}\text { HRT 4 } \\
\text { days }\end{array}$ & $\begin{array}{c}\text { HRT 6 } \\
\text { days }\end{array}$ & $\begin{array}{c}\text { HRT 8 } \\
\text { days }\end{array}$ & Average \\
\hline COD & $1010 \pm$ & $618 \pm$ & $868 \pm$ & $832 \pm$ \\
& 464 & 497 & 378 & 198 \\
Total & $1,17 \pm$ & $0,57 \pm$ & $0,66 \pm$ & $0,80 \pm$ \\
Nitrogen & 0,14 & 0,16 & 0,04 & 0,32 \\
Total & $1,47 \pm$ & $0,34 \pm$ & $0,48 \pm$ & $0,76 \pm$ \\
Phosphor & 0,58 & 0,10 & 0,22 & 0,62 \\
Dissolved $\mathrm{O}_{2}$ & $5,40 \pm$ & $2,87 \pm$ & $4,53 \pm$ & $4,27 \pm$ \\
& 1,80 & 2,11 & 3,46 & 1,29 \\
pH & $6,53 \pm$ & $6,21 \pm$ & $7,10 \pm$ & $6,61 \pm$ \\
Temperature & 0,6 & 0,14 & 0,7 & 0,37 \\
$\left({ }^{\circ} \mathrm{C}\right)$ & $27 \pm 3$ & $26 \pm 6$ & $25 \pm 4$ & $26 \pm 0,6$ \\
Chrome $(\mathrm{Cr})$ & $0,47 \pm$ & $0,54 \pm$ & $1,24 \pm$ & $0,74 \pm$ \\
& 0,07 & 0,21 & 0,23 & 0,42 \\
Sulfur $(\mathrm{S})$ & $733 \pm$ & $1113 \pm$ & $937 \pm$ & $928 \pm$ \\
& 102 & 501 & 75 & 190 \\
\hline Standard deviation & & & &
\end{tabular}

\pm Standard deviation

Some parameters analyzed presented large variation among the different treatments applied, as well as, during the performance of each treatment. For the Chemical oxygen demand (COD), for example, variation were observed in a range from 618 to $1010 \mathrm{mg} . \mathrm{L}^{-1}$ between the times studied, as well as the Total Nitrogen and Total Phosphor, which presented variation from 1,17 to $0,66 \mathrm{mg} \cdot \mathrm{L}^{-1}$ and 1,47 to $0,34 \mathrm{mg} \cdot \mathrm{L}^{-1}$ respectively. Pacheco (2005) evaluated the national average concentration of Total $\mathrm{N}$ for gross emission of effluents from the leather processing industry and observed values between 0,1 and $0,2 \mathrm{mg} . \mathrm{L}^{-1}$ Total $\mathrm{N}$ for tanning of leather semi-finished. Studies performed by Cui et al., (2008) using wetland systems to remove nourishments showed that there was a loss of efficiency due to alterations of the nourishments concentration.

\section{Performance of the system on a pilot scale}

Results regarding the performance of the system considering the evaluated parameters are displayed on Figure 2. 

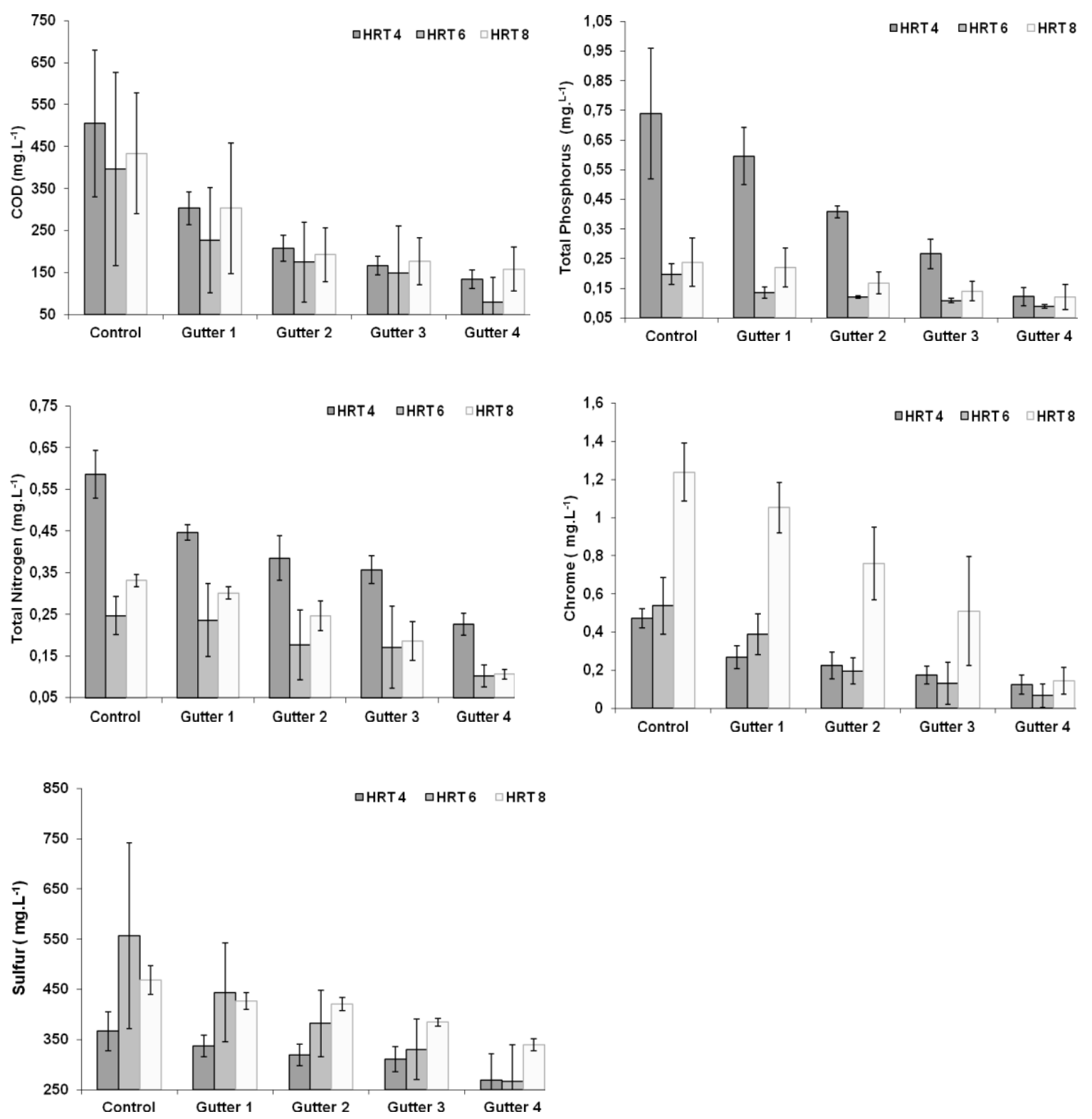

Figura 2. Effluent performance along the treatment system applied. Average values in mg.L $\mathrm{L}^{-1}$ sampled during the HRT evaluated.

\section{Chemical Oxygen Demand - COD}

Regarding the COD reduction, it can be observed that the removal obtained was similar for every retention time evaluated, with reductions of $73,4 \%, 79,9 \%$ and $63,5 \%$ for the HRT 4, 6 and 8 days, respectively, where the higher reduction observed was on HRT 6 days. Some researchers observed similar results when evaluation built wetlands, testing not only emergent plants such as Phragmites communis and Typha orientalis, but also floating plants such as Pistia stratiotes and Eichhornia crassipes. Regarding the results obtained, the 
removal of carbonaceous matter, expressed as COD, of $64 \%$ to $97 \%$ evaluated in retention times of 2, 4, 5 and 7 days (Chen et al., 2008; Jou et al., 2009).

For the three retention times evaluated, the performance was similar, presenting significant reduction in the two first gutters (> 50\%), where the final organic load remained between 80 - $158 \mathrm{mg} . \mathrm{L}^{-1} \mathrm{COD}$, therefore, within the acceptable levels imposed by the current legislation (CONAMA, 2005).

\section{Phosphor}

Phosphor does not present sanitary problems in water supplies, but it is the effluent constituent that is more associated to the eutrophication of superficial water, where its disposal is limited to $0,1 \mathrm{mg} . \mathrm{L}^{-1}$ of total phosphor for disposal at lotic environments and tributaries of intermediary environments (CONAMA, 2005). On the evaluation of the total phosphor by the proposed system, it presented similar efficiency of removal at 6 and 8 days with reductions of $54,8 \%$ and $49,2 \%$ of the initial concentration, achieving $83,5 \%$ in 4 days. However, despite of the significant reduction, the system is ineffective for the treatment of this parameter, exceeding the maximum load tolerated by the legislation.

In a study using the constructed wetland for removal of $\mathrm{P}$, was observed that the percentage reduction in the nutrient decreased from $82 \%$ to $33.2 \%$, due to variations in the concentration in the initial system entry (Cui et al., 2008).

\section{Total Nitrogen}

The form that nitrogen incorporates the biomass of macrophyte is by assimilation. This process refers to a variety of biological processes that convert inorganic forms of nitrogen into organic compounds. These compounds work as a reservoir for the cell and tissues of the plants (Kadlec et al, 2000). For total nitrogen, the reduction observed at the system was $61,4 \%, 58,7 \%$ and $68 \%$, for the times of 4,6 and 8 days respectively. Similarly to COD and total phosphor, the initial concentration of the effluent for the HRT 4 days was higher than the other times evaluated. However, it did not interfered the performance of the system, where the final concentrations of total nitrogen were from 10 to $0,22 \mathrm{mg} . \mathrm{L}^{-1}$ of Total N. Similar results were obtained in two wetland systems, one with superficial flow and the other with subsurface flow, with wastewater contamined by nitrate, on which, reductions between $60 \%$ and $85 \%$ were observed (Sousa, et al., 2003; Ying-Feng et al., 2008).

Revista Brasileira de Energias Renováveis, v. 3, p. 1-12, 2014 
Despite of the removal obtained, higher concentrations of nourishment can limit the rate of nitrate removal from a biological process of denitrification (USEPA, 2000;Tang et al., 2008; Tang et al., 2009).

\section{Chrome}

Chrome is the main problem of tannery, because it is the input used by most of the companies in the tanning process. This is one of the human activities mainly responsible by its release to the environment (Hafez et al, 2002; Pacheco, 2005). Chrome has its release limited to $0,55 \mathrm{mg} . \mathrm{L}^{-1}$ of $\mathrm{Cr}$ for effluent emissions of any type of source in water bodies (CONAMA, 2005).

According to Figure 2, at the end of all retention times that were evaluated, chrome presented results within the standard of effluent emission, currently established, on which the reductions obtained were $73,7 \% ; 87,7 \%$ and $88,3 \%$ for HRT 4, 6 and 8 days, respectively. By the end of the system, the effluent presented concentrations between 0,065 to $0,14 \mathrm{mg} \cdot \mathrm{L}^{-1}$ of $\mathrm{Cr}$, similar to the ones obtained by studies performed by Pacheco (2005), between 0,1 to 0,2 mg. $\mathrm{L}^{-1}$ of $\mathrm{Cr}$ for emissions preliminary post-treatment, primary treatment or physicalchemical and biological treatment.

Chrome toxicity depends of the oxidation state on which it is disposed in the effluent. Most of its soluble compounds, in superficial water, can be presented as hexavalent chrome $\left(\mathrm{Cr}^{+6}\right)$, and a small part as chrome $\left(\mathrm{Cr}^{+3}\right)$ in organic complexes. Hexavalent chrome can, however, be reduced to chrome $\left(\mathrm{Cr}^{+3}\right)$ by organic matters existent in the water and can, eventually, deposit itself on the sediments. Chrome assimilation by macrophytes can be also considered, once many metals are required for their growth (traces) (Knox et al., 2006; Espinoza-Quinoñes et al., 2008).

\section{Sulfur}

Sulfur, as sulfide, also exists in the tannery disposal and it is a high toxicity compound that brings discomfort at the treatment installations. Soluble in alkaline aqueous solutions, with the lowering of $\mathrm{pH}$ values, sulfide ion is connected to the hydrogen ion existent in the solution, forming $\mathrm{H}_{2} \mathrm{~S}$, hydrogen sulfide, hydrogen sulfide or hydrogen sulfide (Pacheco, 2005). At the treatment system proposed, the results regarding the final concentrations of sulfur were 269,51, 267,30 and 339,58 mg.L $\mathrm{L}^{-1}$ for HRT 4, 6 and 8 days, 
respectively. Between the evaluated retention times, HRT 6 days presented the best result, with $52 \%$ reduction, meanwhile, HRT 4 and 8 days presented reduction of 26,5 and $27,6 \%$.

Amongst the parameters evaluated on the experiment, sulfur as sulfide ion was the one that presented the lowest reduction rate, which can be explained by its high concentration on the system (Kadlec, et al., 2000; Cui et al., 2008). Sulfide, existent in the effluents of the tannery treatment, is the most toxic compound for the human being, more toxic then chrome from tannery, considering that the last one is in its trivalent form (Pacheco, 2005).

\section{Conclusions}

Altogether, the hydraulic retention time of 6 days was the one that presented better results on the removal of the parameters evaluated, presenting satisfactory results regarding the removals, being within the limits established by the current legislation for effluent disposal from polluting sources.

For total phosphor and sulfur, the system was not proved to be effective, not being able to reach the minimal standards of disposal, for these nourishments.

The system presented operational limitations with the tannery effluent used, considering the large variation of composition and high initial concentrations of operation, especially for sulfur. 


\section{Bibliographic Review}

Álvarez j. A., Bécare E. (2008). The Effect of Plant Harvesting on the Performance of a Free Water Surface Constructed Wetland. Environmental Engineering Science Volume 25, Number 8.

Chen S.W., Kao C.M., Jou C.R., Fu Y.T., Chang Y.I. (2008). Use of a Constructed Wetland for Post-Treatment of Swine Wastewater Environmental Engineering Science. Volume 25, Number 3 ..

CONSELHO NACIONAL DO MEIO AMBIENTE - CONAMA. Resolução CONAMA Nº 357/2005.

Cui L,; Zhu X.; Ma M.; Ouyang Ying; Dong M.; Zhu W.; Luo S. (2008). Phosphorus Sorption Capacities and Physicochemical Properties of Nine Substrate Materials for Constructed Wetland. Arch Environ Contam Toxicol vol. 55: p.210-217.

Espinoza-Quiñones F. R.; Silva E. A.; Rizzutto M. A.; Palácio S. M.; Módenes A. N.; Szymanski N.; Martin N.; Kroumov A. D. (2008). Chromium ions phytoaccumulation by three floating aquatic macrophytes from a nutrient médium. World J Microbiol Biotechnol vol.24, p:3063-3070.

Espinoza-Quiñones, F. R.; Zacarkim, C.; Palácio, S. M.; Zenatti, D. C. ; Obregón, C. L.; Galante, R. M.; Rossi, N.; Rossi, F. (2005). Removal of heavy metal from polluted river water using aquatic macrophytes Salvinia sp. Brazilian Journal of Physics.

Hafez, A.I., El-Manharawy, M.S., Khedr, M.A., RO. (2002). Membrane Removal Of Unreacted Chromium From Spent Tanning Effluent. A Pilot-Scale Study, Part 2. Desalination 144, 237-242.

Hedmark A., Scholz M., Elowson T. (2009). Treatment of Log Yard Runoff Impacted by Aged Logs in a Free Water Surface Constructed Wetland Environmental Engineering Science Volume 26, Number 11.

Hu C. Shan B.(2009). Phosphorus Removal Performance and Mechanisms of a Constructed Horizontal Subsurface Flow Wetlands Treating Reclaimed Water. Environmental Engineering Science, Volume 26, Number 6.

Imhoff, K.(1985). Manual for Wastewater Treatment [Manual de Tratamento de águas Residuárias]. 26ª edição. São Paulo: Editora Egard Blücher Ltda, p.301.

INTERNATIONAL WATER ASSOCIATION.(2000). Constructed Wetlands for Pollution Control. Processes, Performance, Design and Operation. IWA Publishing, London.

Jou C.-J., Chen S. W., Tseng K H., Kao C. M. (2009). Efficiency and Ecological Benefits of Purifying Wu-Lo Creek with a Constructed Wetland System. Environmental Engineering Science, Volume 26, Number 1.

Kadlec, R. H; Knight, R. L; Vymazal, J; Brix, H; Cooper, P; Haberl, R. (2000). Constructed Wetlands for Pollution Control: process, performance, design and operation - Scientific and Technical Report, London: IWA Publishing, n. 8, p.156.

Knox, A. Paller M. H., Nelson E. A., Specht W. L., Halverson N. V., Gladden J. B.(2006). Metal Distribution and Stability in Constructed Wetland Sediment. J. Environ. Qual. p.35:1948-1959.

Revista Brasileira de Energias Renováveis, v. 3, p. 1-12, 2014 
Lin Y. F, Jing S. R, Lee D. Y, Chang Y. F, Chen Y. M, Shih K. C. (2005) Performance of a constructed wetland treating intensive shrimp aquaculture wastewater under high hydraulic loading rate. Environmental Pollution, v.134, pp.411-421.

McJannet, D., Wallace, J., Keen, R., Hawdon, A. and Kemei, J. (2012), The filtering capacity of a tropical riverine wetland: II. Sediment and nutrient balances. Hydrol. Process., 26: 53-72. doi: 10.1002/hyp.8111

Pacheco, J. W. F. (2005) Tanneries [Curtumes]. São Paulo: CETESB,. p. 76 - (Série P + L). Disponível em : <http://www.cetesb.sp.gov.br>.

Ruan X., Xue Y., Wu J.,Ni L. Sun M., Zhang X. (2006). Treatment of Polluted River Water Using Pilot-Scale Constructed Wetlands. Bull. Environ. Contam. Toxicol. p.:90-97.

Sousa, J. T. de, Haandel, A. V. C . Guimarães, A.V.A. (2003). Performance of constructed wetland systems treating anaerobic effluents. Water Science and Technology, v.48, n.6, p. 295-299.

Tang X., Huang S., Ng C., Li J. (2009). Enhancement of Nitrogen and Phosphorus Removal in Pilot-Scale Vertical Subsurface Flow-Constructed Wetlands Using Polypropylene Pellets. Environmental Engineering Science, Volume 26, Number 3.

Tang X., Huang S., Scholz M., (2008). Nutrient Removal in Wetlands During Intermittent Artificial Aeration. Environmental Engineering Science Volume 25, Number 9.

U.S. Environmental Protection Agency. (2000b). Manual Constructed Wetlands for Municipal Wastewater Treatment. EPA 625-R-99-010, US EPA ORD, Cicinnati: Ohio.

Ying-Feng L., Shuh-Ren J., Der-Yuan L., Yih-Feng C., Kai-Chung S. (2008). Nitrate removal from groundwater using constructed wetlands under various hydraulic loading rates. Bioresource Technology 99 p. 7504-7513. 